\title{
Curva de crescimento de calos de Enterolobium contortisiliquum induzidos in vitro
}

\author{
Calli growth curve of Enterolobium contortisiliquum in vitro induced \\ Curva de crecimiento del callos de Enterolobium contortisiliquum inducido in vitro
}

Filipe Almendagna Rodrigues

ORCID: https://orcid.org/0000-0003-2433-4374 Universidade Federal de Lavras, Brasil

E-mail: filipealmendagna@yahoo.com.br Vytória Piscitelli Cavalcanti

ORCID: https://orcid.org/0000-0003-4539-2477 Universidade Federal de Lavras, Brasil E-mail: vytoriapc@yahoo.com.br

Joyce Dória

ORCID: https://orcid.org/0000-0002-7727-5016 Universidade Federal de Lavras, Brasil E-mail: joyce.doria@ufla.br

Moacir Pasqual

ORCID: https://orcid.org/0000-0001-5612-9186 Universidade Federal de Lavras, Brasil E-mail:mpasqual@ufla.br

\begin{abstract}
Resumo
O objetivo do trabalho foi determinar in vitro a curva de crescimento de calos de Enterolobium contortisiliquum. Foram utilizados calos advindos dos cotilédones de E. contortisiliquum cultivados em meio MS, suplementado com $0,5 \mathrm{mg} \mathrm{L}^{-1}$ de 2,4-D + 2,0 $\mathrm{mg} \mathrm{L}^{-1}$ de picloram $+0,5 \mathrm{mg} \mathrm{L}^{-1}$ de cinetina $+2,0 \mathrm{mg} \mathrm{L}^{-1}$ de BAP e repicados duas vezes, em intervalos de 30 dias. Após a segunda repicagem, foi estabelecida a curva de crescimento dos calos por meio da determinação da massa fresca (mg) a partir do dia da inoculação (tempo 0). O delineamento experimental foi inteiramente casualizado com 17 tratamentos, constituídos pelos intervalos de avaliação $(0,7,14,21,28,35,42,49$, 56, 63, 70, 77, 84, 91, 98, 105 e 112 dias), e 24 repetições. O E. contortisiliquum apresentou cinco fases de desenvolvimento de calos: exponencial, linear, desaceleração, estacionário e declínio. A curva de crescimento do calo para a espécie E. contortisiliquum começou com a fase exponencial e permaneceu nesta fase dos dias 0 a 7 . Já o período de crescimento linear em que diminuiu a taxa de divisão celular e aumentou a área celular foi observado entre os dias 7 e 14. Enquanto a fase de desaceleração ocorreu dos 14 aos 28 dias. Conclui-se que a curva de crescimento dos calos de E. contortisiliquum é uma sigmoide com cinco fases e ao final da desaceleração é o momento de se realizar a repicagem dos calos, em média aos 28 dias de cultivo in vitro.
\end{abstract}

Palavras-chave: Cultura de tecidos vegetais; Reguladores de crescimento; Metabólitos secundários.

\begin{abstract}
The objective of this work was to determine in vitro the growth curve of Enterolobium contortisiliquum calli. Calli from E. contortisiliquum cotyledons cultivated in MS medium, supplemented with $0.5 \mathrm{mg} \mathrm{L}^{-1} 2,4-\mathrm{D}+2.0 \mathrm{mg} \mathrm{L}^{-1}$ picloram $+0.5 \mathrm{mg} \mathrm{L}^{-1}$ kinetin $+2.0 \mathrm{mg} \mathrm{L}^{-1} \mathrm{BAP}$ and repeated twice were used., at intervals of 30 days. After the second subculture, the calli growth curve was established by determining the fresh mass $(\mathrm{mg})$ from the day of inoculation (time 0). The experimental design was completely randomized with 17 treatments, constituted by the evaluation intervals $(0,7,14,21,28,35,42,49,56,63,70,77,84,91,98,105$ and 112 days), and 24 repetitions. $E$. contortisiliquum presented five phases of callus development: exponential, linear, deceleration, stationary and decay. The calli growth curve for the species E. contortisiliquum started with the exponential phase and remained in this phase from days 0 to 7 . The linear growth period in which the cell division rate decreased and the cell area increased was observed between the days 7 and 14. While the deceleration phase occurred from 14 to 28 days. It can be concluded that the growth curve of E. contortisiliquum calli is a sigmoid with five phases and at the end of the deceleration it is time to carry out the calli subculture, on average at 28 days of in vitro culture.
\end{abstract}

Keywords: Plant tissue culture; Growth regulators; Secondary metabolites.

\section{Resumen}

El objetivo de este trabajo fue determinar in vitro la curva de crecimiento de callos de Enterolobium contortisiliquum. Se utilizaron callos de cotiledones de E. contortisiliquum cultivados en medio MS, suplementados con $0.5 \mathrm{mg} \mathrm{L}^{-1} \mathrm{de}$ 2,4-D + $2.0 \mathrm{mg} \mathrm{L}^{-1}$ de picloram $+0.5 \mathrm{mg} \mathrm{L}^{-1}$ de kinetina $+2.0 \mathrm{mg} \mathrm{L}^{-1}$ de BAP y repetido dos veces, a intervalos de 30 
días. Después del segundo subcultivo, se estableció la curva de crecimiento del callo determinando la masa fresca (mg) desde el día de la inoculación (tiempo 0). El diseño experimental fue completamente aleatorizado con 17 tratamientos, constituido por los intervalos de evaluación $(0,7,14,21,28,35,42,49,56,63,70,77,84,91,98,105$ y 112 días) y 24 repeticiones. E. contortisiliquum presentaba cinco fases de desarrollo de callos: exponencial, lineal, desaceleración, estacionaria y decadencia. La curva de crecimiento del callo para la especie E. contortisiliquum comenzó con la fase exponencial y permaneció en esta fase desde los días 0 a 7 . El período de crecimiento lineal en el que la tasa de división celular disminuyó y el área celular aumentó se observó entre los días 7 y 14 Mientras que la fase de desaceleración se produjo de 14 a 28 días. Conclui que la curva de crecimiento de los callos de $E$. contortisiliquum es sigmoidea con cinco fases y al final de la desaceleración es el momento de realizar el subcultivo del callo, en promedio a los 28 días de cultivo in vitro.

Palabras clave: Cultivo de tejidos vegetales; Reguladores del crecimiento; Metabolitos secundarios.

\section{Introdução}

Enterolobium contortisiliquum (Vell.) Morong. é uma espécie de planta arbórea do bioma Cerrado, pertencente à família Fabaceae e comumente conhecida como tamboril, podendo alcançar mais de $4 \mathrm{~m}$ de altura. Por isso, tem sido muito aproveitada para reflorestamento, bem como para a recuperação de áreas degradadas (Lorenzi, 2008). Atualmente, diversos estudos vêm sendo conduzidos com a espécie a fim de se investigar o seu potencial na produção de metabólitos secundários que possam ser aproveitáveis para a indústria (Farias et al., 2010; Miranda et al., 2015; Matloub et al., 2018; Abdel-Mageed et al., 2019). Dessa maneira, a produção de metabólitos in vitro tem o potencial de superar os baixos rendimentos e a sazonalidade da produção quando essas substâncias são extraídas a partir da fonte natural. No entanto, existem inúmeras estratégias para estimular a produção específica do metabólito de interesse (Dong \& Zhong, 2001; Hu et al., 2001; Wang \& Zhong, 2002; Fumagali et al., 2008).

A cultura de tecidos é uma técnica biotecnológica que possibilita a produção de biomassa em grande escala, curto espaço de tempo e pequeno espaço físico. Uma das formas de ser obter tal objetivo é por meio do cultivo in vitro de calos que, segundo Torres et al. (2000), é uma massa de células com crescimento desordenado, e que podem apresentar certo grau de diferenciação. Além disso, o calo é uma resposta morfológica da planta a uma injúria que lhe é causada. In vitro, tal resposta se dá por injúria a um tecido, seja de forma física ou química, podendo ocasionar diferenciação, que é o objeto de estudo.

No entanto, a produção de calos também pode ser influenciada pela composição do meio de cultura e reguladores de crescimento. Segundo Pierik (1990), geralmente, concentrações semelhantes de auxina e citocinina presentes no meio de cultura podem promover a formação de calos, no entanto, esse efeito pode variar em função do balanço hormonal endógeno em cada tipo de explante. Dessa forma, através da técnica da curva de crescimento de calos é possível ampliar o conhecimento de fisiologia do desenvolvimento de uma espécie, sendo de extrema importância, pois permite a identificação das diferentes fases de crescimento do calo, e dessa forma, possibilitar a repicagem dos explantes no momento mais adequado, podendo potencializar sua morfogênese.

Segundo Smith (1992), a curva de crescimento de calos pode exibir cinco fases distintas: lag, exponencial, linear, desaceleração e estacionária. Essas cinco fases normalmente se congregam em um comportamento sigmoidal e o platô final dessa sigmoide representa a fase estacionária. Nessa fase, as células não estão mais em divisão celular, por isso o crescimento se estabiliza. Portanto, se o objetivo é a multiplicação do explante, a repicagem não deve ultrapassar essa fase, pois a multiplicação demanda alta divisão celular. O cessar de crescimento na fase estacionária pode ser devido a uma característica da espécie ou à carência nutricional. De qualquer forma, denota-se que o explante necessita de um novo estímulo para continuar se desenvolvendo. Sendo assim, pode-se inferir esta fase como o momento ideal para repicagem do calo ou a transferência de massas calogênicas para o novo meio de cultura.

A curva de crescimento de calo é relatada como objeto de estudo em diversas espécies lenhosas, como café (Santos et al., 2003), detectado o crescimento tipo sigmoide, mas somente com três fases distintas: lag (0 - 42 dias de inoculação), 
exponencial (42 - 77 dias) e linear (77 - 84 dias). Pereira et al. (2007) estudaram a curva de calos em função de diferentes reguladores em unha-de-gato, e identificaram comportamento diferente quanto à estabilização para cada regulador (picloram 25 dias de cultivo e 2,4-D (ácido 2,4-diclorofenoxiacético), ANA (ácido nafataleno acético) e AIB - 30 dias de cultivo), mas observaram sempre uma sigmoide. Enquanto Nogueira et al. (2008) observaram a curva de crescimento padrão sigmoide, com seis fases distintas de crescimento em murici-pequeno, e repicagem aos 60 dias. Por outro lado, Silva et al. (2020) observaram que a curva de crescimento de calos de aroeira-do-sertão (Myracrodruon urundeuva) apresenta forma sigmoidal contendo cinco fases (lag, exponencial, linear, desaceleração e estacionária). Fato também observado por Abbade et al. (2010), que identificaram uma sigmoide com cinco fases distintas em ipê-branco, além disso, recomendam a repicagem aos 60-75 dias; e Rossato et al. (2019) que observaram em segmentos nodais de gabiroba (Campomanesia adamantium) a curva de crescimento de calos, com a presença das fases de atraso (0-7 dias), exponencial (7-28 dias), crescimento linear (28-35 dias), desaceleração (35-42 dias) e estacionária (após 42 dias).

Sendo assim, o objetivo do trabalho foi determinar in vitro a curva de crescimento de calos de Enterolobium contortisiliquum.

\section{Metodologia}

Sementes de Enterolobium contortisiliquum provenientes da cidade de Coronel Murta-MG, Brasil, foram estabelecidas in vitro.

Inicialmente, foi retirado o tegumento das sementes com auxílio de bisturi e, logo após, submetidas ao procedimento de assepsia que consistiu da imersão em água destilada, com duas gotas de Tween-20 por 1 min, seguida de imersão em álcool $70 \%$ v/v por 1 min, e finalmente em solução de hipoclorito de sódio a 1\% por 20 min, sob agitação constante. Posteriormente, os agentes desinfetantes foram lixiviados por tríplice lavagem em água destilada estéril.

Após a assepsia em câmara de fluxo laminar, cotilédones foram separados do eixo embrionário para evitar a germinação da semente. Os cotilédones foram individualizados em tubos de ensaio de $25 \times 150 \mathrm{~mm}$ contendo $15 \mathrm{~mL}$ do meio de cultivo MS (Murashige \& Skoog, 1962) e suplementado com fitorreguladores de acordo com cada tratamento.

Calos advindos de um dos cotilédones, cultivados em meio MS, suplementado com 0,5 $\mathrm{mg} \mathrm{L}^{-1}$ de 2,4-D + 2,0 $\mathrm{mg} \mathrm{L}^{-1}$ de picloram $+0,5 \mathrm{mg} \mathrm{L}^{-1}$ de cinetina $+2,0 \mathrm{mg} \mathrm{L}^{-1}$ de BAP, foram repicados duas vezes, em intervalos de 30 dias. Após a segunda repicagem, foi estabelecida a curva de crescimento dos calos por meio da determinação da massa fresca a partir do dia da inoculação (tempo 0), em intervalos de sete dias, durante 112 dias (Santos et al., 2013).

O delineamento experimental foi inteiramente casualizado (DIC) contendo 17 tratamentos, sendo representados pelos intervalos de avaliação $(0,7,14,21,28,35,42,49,56,63,70,77,84,91,98,105$ e 112 dias), e 24 repetições compostas por um tubo de ensaio contendo um explante (calo). A curva de crescimento foi plotada a cada sete dias através do software Excel®.

\section{Resultados e Discussão}

O padrão cinético para uma curva de crescimento de calo é sigmoidal, e compreende fases lag, exponencial, linear, desaceleração e estacionária. Este comportamento já foi observado em várias espécies lenhosas, como Bertholletia excelsa (Serra et al., 2000) e Byrsonima intermedia A. Juss. (Abbade et al., 2010). No entanto, nem todas as fases são necessariamente observadas; a exemplo de Stein et al. (2010), que não identificaram a fase estacionária em calos de Inga vera Wild. 
No presente trabalho a fase de atraso estava ausente, mas a fase de declínio foi identificada. Assim, a espécie Enterolobium contortisiliquum apresentou cinco fases de desenvolvimento de calos: exponencial, linear, desaceleração, estacionário e declínio (Figura 1).

Figura 1. Massa fresca de calos (mg) de E. contortisiliquum mensurada a cada 7 dias de avaliação.

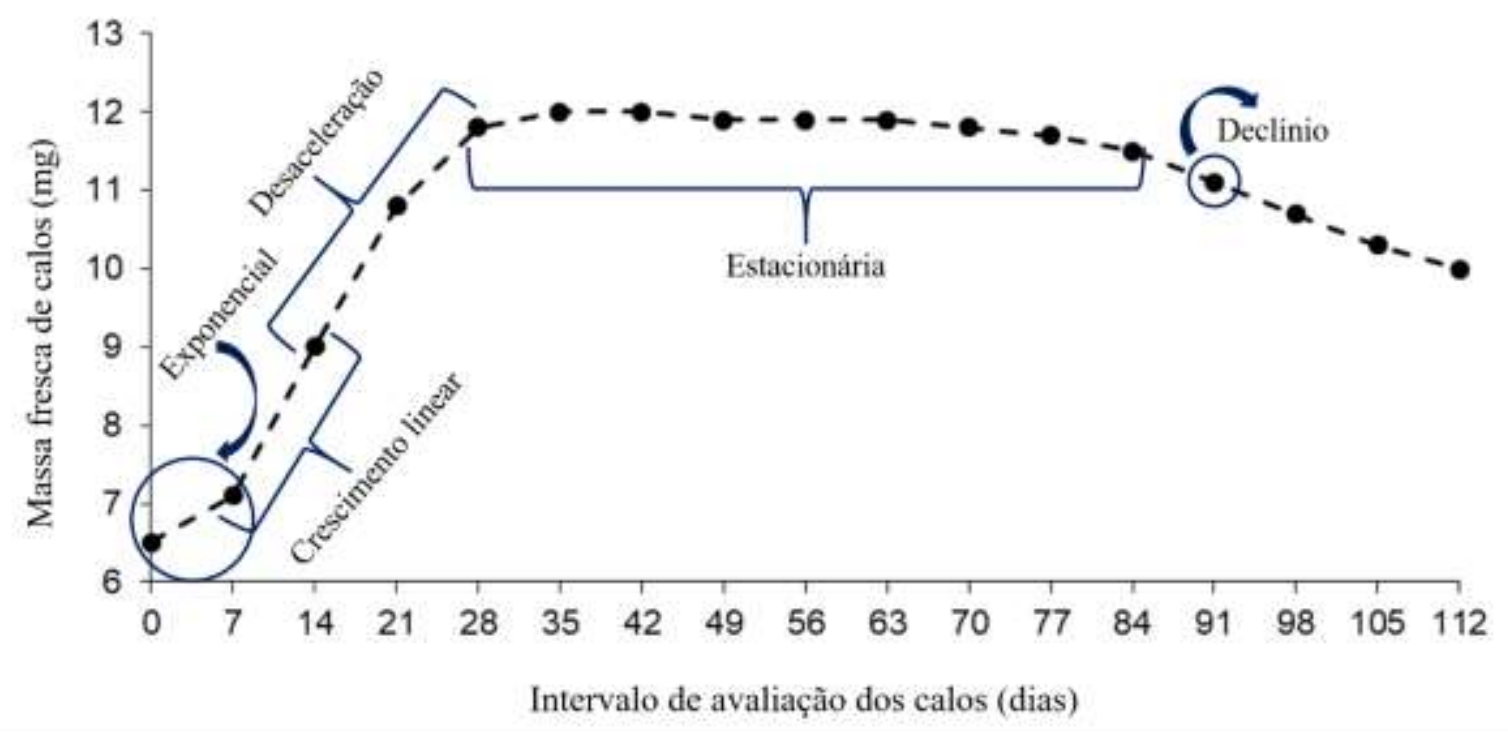

Fonte: Autores.

A fase de atraso não foi identificada na curva de crescimento de calo E. contortisiliquum. Os intervalos de avaliação foram de 7 dias, no entanto, como esta é a fase de preparação para a divisão celular, provavelmente durou menos de 7 dias e, consequentemente, não foi de ser identificada. Contudo, Serra et al. (2000) demonstraram que a fase de atraso é prolongada quando é utilizada como explante inicial a folha de B. excelsa.

A curva de crescimento do calo de E. contortisiliquum começou com a fase exponencial, em que a divisão celular já era pronunciada, e permaneceu nesta fase dos dias 0 a 7 . Em contraste, a curva de crescimento do calo começa com a fase de atraso para B. intermedia (Abbade et al., 2010). O período de crescimento linear, que diminuiu a taxa de divisão celular e aumentou a área celular (Smith, 1992), foi observado entre os dias 7 e 14. Este breve período é devido ao tecido homogêneo, pois é um explante secundário (Serra et al., 2000).

A fase de desaceleração compõe o período dos dias 14 a 28. De acordo com Smith (1992), o calo deve ser subcultivado durante a fase de desaceleração, porque as células não se dividem pela fase estacionária média. Dessa forma, os calos de E. contortisiliquum devem ser subcultivados aproximadamente 28 dias após o crescimento. A fase estacionária continuou até o dia 77.

Vale ressaltar que nesta fase, o crescimento cessou, mas o desenvolvimento dos processos, tal como diferenciação, estava ativo. No dia 84, os calos de E. contortisiliquum entraram na fase de declínio, em que o desenvolvimento também cessou porque o calo estava em senescência.

\section{Conclusões}

A curva de crescimento dos calos de Enterolobium contortisiliquum é uma sigmoide com cinco fases. Ao final da desaceleração é o momento em que deve-se realizar a repicagem dos calos (em média aos 28 dias de cultivo in vitro). 


\section{Agradecimentos}

Os autores agradecem o apoio financeiro das agências CAPES, CNPq e FAPEMIG.

\section{Referências}

Abbade, L. C., Paiva, P. D. O., Paiva, R. \& Graciano, M. H. P. (2010). Growth curve and biochemical analyses of callus of ipê-branco (Tabebuia roseo alba (Ridl.) Sand). Naturale, 33, 45-56.

Abdel-Mageed, W. M., Al-Wahaibi, L. H., Gouda, Y. G., Al-Saleem, M. S. M., El-Gamal, A. A., Basudan, O. A., Alsaid, M. S., Al-Massarani, S. M. \& Abdel-Kader, M. S. (2019). Contortisiliosides H-M: Triterpenoid saponins from Enterolobium contortisiliquum and their biological activity. Industrial Crops and Products, 139, 111528

Dong, H. D. \& Zhong, J. J. (2001). Significant improvement of taxane production in suspension cultures of Taxus chinensis by combining elicitation with sucrose feed. Biochemical Engineering Journal, 8, 145-150.

Farias, D. F., Cavalheiro, M. G., Viana, M. P., Queiroz, V. A., Rocha-Bezerra, L. C. B., Vasconcelos, I. M., Morais, S. M. \& Carvalho, A. F. U. (2010). Water extracts of Brazilian leguminous seeds as rich sources of larvicidal compounds against Aedes aegypti L. Anais da Academia Brasileira de Ciências, 82 (3), $585-594$.

Fumagali, E., Gonçalves, R. A. C., Machado, M. F. P., Vidoti, G. J. \& Oliveira, A. J. B. (2008). Revista Brasileira de farmacognosia, 18 (4), $627-641$.

Hu, W. W., Yao, H. U. \& Zhong, J. J. (2001). Improvement of Panax notoginseng cell cultures for production of ginseng saponin and polysaccharide by highdensity cultivation of pneumatically agitated bioreactors. Biotechnology Progress, 17, 838-846.

Lorenzi, H. Árvores Brasileiras: Manual de identificação e cultivo de plantas arbóreas nativas do Brasil.: Ed. Plantarum, 1992. 365p.

Matloub, A. A., Mohammed, R. S., Elsouda, S.S., El-Hallouty, S. M., Gomaa, E. Z. \& Hassan, A. A. (2018). Phytochemical and biological studies on Enterolobium contortisiliquum (Vell.) Morong Pericarps. Journal of Materials. Environmental Science, 9, $2768-2778$.

Miranda, M. L. D., Garce, F. R. \& Garcez, W. S. (2015). Triterpenes and other constituents from fruits of Enterolobium contortisiliquum (Vell.) Morong (Fabaceae). Revista Virtual de Química, 7, 2597-2605.

Murashige, T. \& Skoog, F. (1962). A revised medium for rapid growth and bioassays with tobacco tissue cultures. Physiology Plantarum, 15 , $473-497$.

Pereira, R. C., Pinto, J. E. B. P., Reis, E. S., Corrêa, R. M. \& Bertolluci, S. K. V. (2007). Influence of different auxins in the induction and callus growth of Uncaria guianensis J. F. GMEL. Plant Cell, Culture and Micropropagation, 3, 69-77.

Pierik, R. L. M. Cultivo in vitro de las plantas superiores. Madrid: Mundi-Prensa, 1990. 326p.

Rossato, M., Schumacher, P. V., Costa Netto, A. P., Stein, V. C., Reis, E. F., Vilela, M. S. P. \& Paiva, L. V. (2019). Embryogenic potential of the callus of gabirobeira, Campomanesia adamantium (Cambess) O. Berg. Acta Scientiarum. Biological Sciences, 41, (1), e46358.

Santos, D., Nunes, C. F., Soares, J. D. R., Valente, T. C. T., Alves, E. L., Gontijo, C. R. \& Pasqual, M. (2013). Cytological characterization of Jatropha curcas callus in different periods of cultivation. Crop Breeding and Applied Biotechnology, 13 (4), 228-233.

Santos, C. G., Paiva, R., Paiva, P. D. O. \& Paiva, E. (2003). Indução e análise bioquímica de calos obtidos de segmentos foliares de Coffea arabica L., cultivar Rubi. Ciência \& Agrotecnologia, 27 (3), 571-577.

Serra, A. G. P., Paiva, R. \& Paiva, P. D. O. (2000) Análises bioquímicas de calos formados de explantes foliares de castanha do Brasil (Bertholletia excelsa H. B. K.). Ciencia \& Agrotecnologia, 24, 833-840.

Silva, T. S., Carvalho Filho, R. S. L., Tanan, T. T., Rocha, T. C. \& Santana, J. R. F. (2020). Ciência Florestal, 30, (3), $700-717$.

Smith, R. H. (1992). Plant tissue culture: techniques and experiments. Academic, 231p.

Stein, V. C., Paiva, R., Herrera, R. C. \& Vargas, D. P. (2010). Curva de crescimento e índice de divisão celular de calos de ingazeiro. Revista Ciências Agrarian, 53, 159-163.

Torres, A. C., Caldas, L. S., Buso, J. A., SÁ, M. F. G. de, Nascimento, A. S., Brígido, M. de M. \& Pinho, E. R. C. Glossário de biotecnologia vegetal. Brasília: EMBRAPA Hortaliças, 2000. 128 p.

Wang, Z. Y. \& Zhong, J. J. (2002). Combination of conditioned medium and elicitation enhances taxoid production in bioreactor cultures of Taxus chinenesis cells. Biochemical Engineering Journal, 12, 93-97. 